\title{
KESIAPSIAGAAN KELUARGA DENGAN PENYAKIT KRONIS MENGHADAPI BENCANA GUNUNG BERAPI DI DESA SIDOREJO KECAMATAN KEMALANG KLATEN
}

\author{
Istianna Nurhidayati ${ }^{1}$, Ema Ratna ${ }^{2}$ \\ ${ }^{1,2}$ STIKES Muhammadiyah Klaten \\ Jl. Ir.Soekarno Km 1 Buntalan Klaten Tengah Klaten \\ Email: istiannanurhidayati@gmail.com
}

\begin{abstract}
Abstrak
Latar belakang: Gangguan kondisi kesehatan dan terputusnya perawatan kesehatan rutin dengan fasilitas pelayanan kesehatan akibat terjadinya bencana menjadikan kelompok dengan penyakit kronis menghadapi resiko paparan penyakit menular, gangguan pernapasan, integritas kulit, eksaserbasi dan kematian yang lebih tinggi dibandingkan kelompok biasa pada umumnya. Hal tersebut membuat penderita penyakit kronis rentan terkena dampak bencana yang lebih berat saat bencana terjadi. Tujuan penelitian ini adalah mengetahui kesiapsiagaan keluarga dengan penyakit kronis pada kejadian bencana

Metode: Penelitian ini dilakukan secara korelasional dengan desain penelitian crosssectional. Populasi penelitian ini adalah keluarga dengan penyakit kronis di Desa Sidorejo Kecamatan Kemalang Klaten yang tercatat di Puskesmas Kemalang. Jumlah sampel penelitian sebanyak 35 sampel diambil dengan tehnik total sampling. Instrument yang digunakan adalah kuesioner. analisa data menggunakan uji Chisquare dan Kendall-Tau

Hasil: Keluarga dengan penyakit kronis yang memiliki kesiapsiagaan kategori kurang siap sebanyak 51,4\% dan siap sebanyak 48,6\%. Berdasarkan uji Chi-square tidak terdapat hubungan antara tipe keluarga dengan kesiapsiagaan keluarga dengan penyakit kronis sedangkan berdasarkan uji Kendall-Tau terdapat hubungan antara pendapatan dengan kesiapsiagaan keluarga ( $p$ value <0,05) dan tidak terdapat hubungan antara APGAR keluarga serta tingkat pendidikan dengan kesiapsiagaan keluarga dengan kesiapsiagaan bencana ( $p$ value >0,05)

Kesimpulan: Keluarga dengan penyakit kronis di Desa Sidorejo Kecamatan Kemalang Klaten memiliki kesiapsiagaan dalam kategori kurang siap

Kata Kunci: Keluarga dengan penyakit kronis, kesiapsiagaan, bencana gunung berapi

Rujukan artikel penelitian:

Nurhidayati, I. \& Ratna, E. (2017). Kesiapsiagaan Keluarga dengan Penyakit Kronis Meghadapi Bencana

Gunung Berapi di Desa SidorejoKecamatan Kemalang Klaten. Jurnal Ilmiah Keperawatan Indonesia. Vol. 1

(1): 47-52.
\end{abstract}




\begin{abstract}
Background: Disruption of health conditions and discontinueing routine health care with health care facilities as a result of the disaster to make the group with chronic diseases face the risk of exposure to infectious diseases, respiratory disorders, skin integrity, exacerbations and mortality is higher than an ordinary group. It makes people vulnerable to chronic disease affected more severe when a disaster occurs. The aim of this study was to determine the preparedness of families with chronic disease in the event of disaster

Metode: This research used correlational with cross-sectional study design. The study population was family with a chronic illness in the village Sidorejo Kemalang District of Klaten. Number of samples 35 samples are taken with total sampling technique. The instrument used was a questionnaire. Data analysis using Chi-square and Kendall-Tau

Results: Families with chronic diseases who have preparedness category as much as $51.4 \%$ less prepared and ready as much as 48.6\%. Based on Chi-square test type of family was no correlattion to family preparedness with chronic diseases while Kendall-Tau test based on the relationship between income with family preparedness with $p$ value <0.05 and there was no correlation between Apgar family as well as level of education and family preparedness with disaster preparedness with $p$ value $>$ 0.05 .

Conclusion: Families with chronic diseases in the village Sidorejo Kemalang District of Klaten have preparedness in the category of ready
\end{abstract}

Keywords: Families with chronic diseases, preparedness, Volcano disaster

\title{
PENDAHULUAN
}

Palang Merah Internasional (2016) menggambarkan bencana sebagai suatu kejadian yang luar biasa, tidak terduga dan terjadi tiba-tiba. Bencana dapat terjadi karena pengaruh dari perbuatan manusia dan atau kekuatan alam. Bencana akibat pengaruh manusia antara lain kecelakaan lalulintas, kecelakaan kerja, pelepasan bahan berbahaya dan runtuhnya bangunan. Sedangkan bencana akibat kekuatan alam/bencana alam yaitu badai tropis, suhu panas dan dingin yang ekstrim, angina, banjir, gempa bumi, tanah longsor dan letusan gunung berapi. Bencana alam dapat menyebabkan hilangnya nyawa, cedera atau dampak kesehatan lainnya, kerusakan properti, kehilangan mata pencaharian dan layanan kesehatan, gangguan social dan ekonomi atau kerusakan lingkungan. 
Organisasi Kesehatan dunia (WHO,2016) menyebutkan kelompok rentan saat terjadi bencana antara lain anak-anak, perempuan hamil, lanjut usia, orang dengan malnutrisi dan orang yang memiliki penyakit ataupun gangguan imunitas. WHO memperkirakan pada tahun 2020, penyakit kronis akan mencapai hampir tigaperempat dari semua kematian di seluruh dunia. $71 \%$ kematian karena penyakit jantung iskemik (IHD), 75\% dari kematian akibat stroke, dan 70\% dari kematian akibat diabetes akan terjadi di negara berkembang. Jumlah penderita diabetes di negara berkembang akan meningkat lebih dari 2,5 kali lipat, dari 84 juta pada tahun 1995 menjadi 228 juta pada tahun 2025. Kerentanan kelompok dengan penyakit kronis dalam menghadapi bencana disebabkan oleh gangguan pada kondisi kesehatan dan terputusnya perawatan kesehatan rutin dengan fasilitas pelayanan kesehatan akibat terjadinya bencana sehingga membuat kelompok dengan penyakit kronis menghadapi resiko paparan penyakit menular, gangguan pernapasan, gangguan integritas kulit, eksaserbasi dan kematian yang lebih tinggi dibandingkan dengan kelompok biasa pada umumnya saat menghadapi bencana (Cherry \& Trainer, 2008; Greenough et al, 2008; Pate, 2008; Smith \& Macdonald, 2006 yang disitasi oleh Owens \& Martsolf, 2014; Tomio \& Sato, 2014).

Bencana Badai Katrina yang terjadi di New Orleans, Louisiana, Amerika Serikat pada tahun 2005 menjadi salah satu bencana alam dengan jumlah korban dengan penyakit kronis terbanyak di dunia. Miller dan Arquilla (2008) menyampaikan hasil survei pengungsi Badai Katrina, $41 \%$ pengungsi memiliki 1 kondisi kesehatan kronis, dan ketika jumlah orang dewasa ( usia lebih 18 tahun) dikurangi, didapatkan hasil lebih dari seperempat populasi yang tersisa, orang dewasa yang tinggal di New Orleans, Louisiana, dilaporkan memiliki setidaknya satu penyakit kronis berikut: hipertensi (29\%); asma (12\%); diabetes (9\%); angina atau penyakit jantung koroner (4,6\%); riwayat miokard infark (3\%); atau stroke $(2 \%)$. Gempa bumi yang terjadi di Jepang tahun 2011, tepatnya di wilayah Fukushima, Miyagi dan Iwate dengan kekuatan 9,0 skala richte, menyebabkan 7.197 jiwa tewas dan 10.905 resmi dinyatakan hilang. Sejumlah korban pada kejadian gempa besar di Jepang tahun 2011 mengalami eksaserbasi dan kematian akibat penyakit kronis, 
termasuk hipertensi, diabetes, kanker, dan penyakit pernapasan kronis (Tomio \& Sato, 2014). Bencana tidak hanya melanda Jepang. Negara di Asia lain memiliki resiko bencana dengan intensitas kejadian yang cukup sering. Negara tersebut: Indonesia, Bangladesh, Iran, Pakistan, Philiphina, India, China, Sri Lanka, Myanmar dan Afghanistan juga mengalaminya (Natural Disaster Risk Index oleh Maplecroft ,2010).

Maplecroft (2010) mencatat Indonesia menjadi negara peringkat dua di Asia setelah Bangladesh dan sebelum Iran sebagai negara dengan resiko bencana yang ekstrim terbanyak. Kementrian Kesehatan Republik Indonesia (2015) mencatat selama 5 tahun terakhir, 2010-2014 kejadian bencana di Indonesia mencapai 1.907 kejadian, terdiri dari 1.124 bencana alam, 626 bencana non alam dan 157 bencana sosial. Indonesia yang terletak di pertemuan 3 lempeng tektonik aktif, yaitu lempeng Indo-Australia, lempeng Euro-Asia dan lempeng Pasifik serta berada pada Cincin Api Pasifik sehingga memiliki 400 gunung api yang 130 diantaranya masih aktif dan dapat mengalami erupsi kapan saja membuat Indonesia menjadi daerah yang rawan bencana alam seperti gunung meletus, gempa bumi, tsunami, banjir dan tanah longsor (Rencana Nasional Penanggulangan Bencana/ Renas PB, 2010) ;Priyono, 2014). Dari sekian banyak bencana yang mungkin timbul akibat letak geografis Indonesia, bencana gunung meletus menjadi salah satu bencana alam yang paling mengancam keselamatan masyarakat gunung berapi aktif di Indonesia mengalami peningkatan aktifitas dan erupsi pada 10 tahun terakhir. Sutopo memaparkan berdasarkan data Badan Nasional Penanggulangan Bencana (BNPB, 2014) kejadian bencana letusan gunung berapi di Indonesia, antara lain letusan Gunung Merapi (26 Oktober 2010), Gunung Sinabung (13 September 2013), Gunung Kelud (13 Februari 2014), Gunung Sangeangapi (30 Maret 2014) Gunung Slamet (13 september 2014) dan Gunung Gamalama (18 Desember 2014).

Kabupaten Klaten menjadi salah satu kabupaten di Jawa Tengah yang paling terdampak saat Gunung Merapi mengalami erupsi. Berdasarkan catatan BNPB tahun 2010 Kabupaten Klaten memiliki jumlah pengungsi mencapai 4.321 jiwa dengan korban yang menjalani rawat inap sebanyak 30 orang dan keseluruhan korban 
meninggal sebanyak 36 jiwa akibat letusan Gunung Merapi 2010. Berdasarkan data Kementrian Kesehatan Republik Indonesia menjelaskan lima dampak letusan Gunung Merapi bagi kesehatan antara lain: luka bakar dengan berbagai derajat keparahannya, cedera dan penyakit langsung akibat batu, kerikil, larva dan lain-lain. dampak dari abu gunung merapi yaitu berbagai jenis gas seperti Sulfur Dioksida (SO2), gas Hidrogen Sulfida (H2S), Nitrogen Dioksida (NO2), serta debu dalam bentuk partikel debu, kecelakaan lalu lintas akibat jalan berdebu licin, jatuh karena panik, serta makanan yang terkontaminasi dan perburukan penyakit yang sudah lama diderita pasien/pengungsi. Di lingkup Jateng Kabupaten Klaten memiliki kecamatan Kemalang sebagai kecamatan yang paling besar terkena dampak dari bencana Gunung Merapi 2010. Tercatat 3 desa di Kecamatan Kemalang masuk dalam KRB berdasarkan luas daerah yang terkena awan panas letusan Merapi 2010 yaitu Desa Sidorejo dan Desa Balerante yang masuk dalam KRB II dan Desa Tegalmulyo yang masuk dalam KRB I karena berada paling dekat atau kurang dari 10-15 Km dari puncak Merapi sekaligus kawasan yang paling terdampak bencana letusan Gunung Merapi 2010. Desa Sidorejo menjadi salah satu desa di Kecamatan Kemalang yang paling terdampak bencana Gunung Merapi dengan 18 dusun dan jumlah penduduk beresiko terpapar sebanyak 4144 jiwa (Badan Pusat Statistik (BPS) Kabupaten Klaten, 2016).

Puskesmas Kemalang mencatat, Hipertensi menduduki peringkat pertama daftar 10 besar penyakit pengungsi bencana Gunung Merapi 2010. Kemudian berdasarkan dokumentasi petugas kesehatan Desa Sidorejo tercatat terdapat 51 warga yang menderita penyakit kronis. Hipertensi merupakan penyakit kronis terbanyak yang diderita oleh warga. Tercatat 28 orang mengidap hipertensi, kemudian 7 orang warga menderita ashma, sedangkan Diabetes Melitus dan Arthritis Reumatoid berada diurutan ketiga dengan masing-masing 4 warga yang menderita penyakit tersebut. Penyakit kronis yang diderita oleh warga Sidorejo lainnya yaitu Gagal Ginjal Kronis, hipertiroidisme, vertigo, migraine stroke, gangguan pada jantung dan gastritis kronis. Hasil wawancara dengan warga yang menderita penyakit kronis dan petugas kesehatan setempat didapatkan data, saat bencana Gunung Merapi terjadi, terdapat 
peningkatan kekambuhan penyakit ashma dan hipertensi. Warga yang menderita Ashma mengalami kekambuhan karena terjadinya hujan abu vulkanik, udara dingin dan ruangan pengungsian yang penuh sesak karena banyaknya jumlah pengungsi, sedangkan penyebab meningkatnya kekambuhan hipertensi merupakan akibat dampak langsung ataupun tidak langsung dari kekhawatiran pengungsi merapi terkait dampak yang akan mereka hadapi akibat bencana Gunung Merapi seperti bagaimana mencukupi kebutuhan anggota keluarga selama bencana terjadi sedangkan aktifitas perekonomian tengah berhenti, keselamatan anggota keluarga yang belum dapat terevakuasi, harta benda dan ternak yang ditinggalkan, perbaikan bangunan rumah yang rusak dan lain-lain.

Wawancara dengan petugas kantor Kelurahan Sidorejo didapatkan data bahwa sebagian warga Desa Sidorejo telah memiliki tabungan siaga bencana, yaitu tabungan yang dikumpulkan secara berkala dan yang hanya boleh diambil atau digunakan saat terjadi bencana untuk membantu memenuhi kebutuhan keluarga selama kejadian bencana. Bentuk upaya lain yang dilakukan untuk meminimalkan dampak bencana bagi warga adalah dengan diadakannya latihan simulasi bencana yang dilakukan secara rutin di balai Desa Sidorejo dan warga mengikuti kegiatan yang diselenggarakan berkat kerjasama lembaga-lembaga seperti PMI dan BPBD dengan Tim Siaga Desa (TSD), Tanggap Siaga Bencana (Tagana), Pasag Merapi, Forum Klaster Lereng Merapi (FKLM) dan Organisasi Rakyat (ORA) Merapi dengan antusias (Prihandoko, 2014). Hal tersebut dibenarkan dengan pernyataan petugas kantor Kelurahan Sidorejo yang menyampaikan bahwa Sidorejo telah mendapatkan pelatihan mengenai menejemen bencana yang dilaksanakan oleh berbagai pihak seperti dari Badan Penanggulangan Bencana Daerah (BPBD), Palang Merah Indonesia (PMI), partai-partai politik dan lain-lain. Letak desa yang masuk dalam KRB II Merapi, jumlah penderita penyakit kronis di Desa Sidorejo dan dampak yang dirasakan akibat bencana Merapi bagi penderita penyakit kronis di Desa Sidorejo menjadi alasan untuk perlunya meningkatkan kesiapsiagaan masyarakat Desa Sidorejo khususnya keluarga dengan anggota keluarga yang menderita penyakit 
kronis perlu mendapatkan perhatian khusus agar dampak yang ditimbulkan terhadap kelompk rentan jika bencana terjadi dapat ditekan seminimal mungkin.

Tujuan penelitian ini untuk mengetahui kesiapsiagaan keluarga yang memiliki anggota keluarga dengan penyakit kronis, selain itu untuk mengetahui hubungan karakteristik keluarga dengan kesiapsiagaan keluarga menghadapi bencana gunung berapi.

\section{BAHAN DAN METODE}

Metode yang digunakan dalam penelitian ini adalah pendekatan kuantitatif untuk mengetahui hubungan antar variabel yang diamati. Penelitian menggunakan pendekatan deskriptif yang menggambarkan kesiapsiagaan keluarga dengan penyakit kronis yang tinggal di Desa Sidorejo dalam menghadapi bencana letusan gunung Merapi. Populasi dalam penelitian ini adalah 51 keluarga dengan penyakit kronis di Desa Sidorejo. Sampel dalam penelitian ini adalah ini adalah 35 keluarga dengan penyakit kronis di Desa Sidorejo. Teknik pengumpulan menggunakan metode survey dan wawancara dengan memberikan kuesioner kepada 35 responden kepala keluarga di 4 dukuh yaitu dukuh Karang, Dadapan, Petung dan Semunu. Daftar pertanyaan un tuk mengukur kesiapsiagaan bencana keluarga mengacu pada indikator kesiapsiagaan bencana LIPI-UNESCO 2006 yang telah dimodifikasi dengan pedoman kesiapsiagaan bencana bagi penderita penyakit kronis yang dibuat oleh Departemen Kesehatan Masyarakat dari Kentucky, Amerika Serikat. Responden diberikan 65 butir pertanyaan kuesioner. Analisis dengan menggunakan metode analisis Chi Square dan Kendall-Tau

\section{HASIL DAN BAHASAN}

Hasil penelitian ini dijabarkan dan dibahas berdasarkan literatur yang ada dalam kebencanaan. Hasil dan bahasan meliputi karakteristik keluarga, kesiapsiagaan keluarga dengan penyakit kronik berdasarkan parameter kesiapsiagaan, Kesiapsiagaan keluarga dengan penyakit kronik di Desa Sidorejo, 
serta analisis korelasi karakteristik keluarga dengan kesiaapsiagaan menghadapi bencana gunung berapi di Desa Sidorejo Kecamatan Kemalang.

Tabel 1. Distribusi Frekuensi Karakteristik Responden /Keluarga dengan penyakit kronikdi Desa Sidorejo Tahun $2016(n=35)$

\begin{tabular}{lcc}
\hline \multicolumn{1}{c}{$\begin{array}{c}\text { Karakteristik } \\
\text { Responden }\end{array}$} & F & (\%) \\
\hline Tipe keluarga & & \\
\hline Keluarga besar (extended family) & 17 & 48.6 \\
Keluarga inti (nuclear family) & 18 & 51.4 \\
\hline APGAR Keluarga & & \\
\hline Tidak ada disfungsi & 19 & 54.3 \\
Ada disfungsi & 16 & 45.7 \\
\hline Pendapatan KK & & \\
\hline Diatas UMR & 17 & 48.6 \\
Dibawah UMR & 18 & 51.4 \\
\hline Tingkat Pendidikan KK & & \\
\hline Menengah & 14 & 40.0 \\
Dasar & 21 & 60.0 \\
\hline Total & 35 & 100.0 \\
\hline
\end{tabular}

Hasil penelitian menunjukan sebagian besar keluarga dengan penyakit kronis merupakan tipe keluarga nuclear family $(51,4 \%)$ lebih besar dibandingkan dengan tipe extended family (48,6\%). Jumlah anggota keluarga akan mempengaruhi banyaknya persiapan yang harus dilakukan untuk menghadapi bencana. semakin banyak jumlah anggota keluarga yang dimiliki akan berpengaruh dalam pada koordinasi keluarga pada proses evakuasi/peyelamatan diri. Semakin banyak jumlah anggota keluarga artinya semakin banyak yang harus diselamatkan sehingga diperlukan koordinasi antar anggota keluarga yang lebih baik. Menurut Djafri (2013) kemampuan koordinasi dan perencanaan yang baik antar keluarga akan meningkatkan kesiapsiagaan keluarga dalam mengahadapi bencana.

Hasil penelitian menunjukan sebagian besar kepala keluarga dengan penyakit kronis memiliki APGAR dimana menunjukan bahwa tidak terdapat disfungsi pada keluarga $(54,3 \%)$ lebih besar dibandingkan dengan responden yang memiliki disfungsi keluarga (45,7\%). Hasil APGAR menggambarkan bahwa sebagian besar anggota keluarga yang menderita penyakit kronis memiliki kedekatan yang baik dengan anggota keluarga yang lain. Kedekatan antar keluarga diharapkan akan 
mempengaruhi setiap anggota keluarga dalam hal dukungan dan kepedulian saat melakukan persiapan peralatan yang diperlukan sebelum, saat dan setelah bencana terjadi (Susilawati, 2013).

Hasil penelitian menunjukan sebagian besar responden dengan penyakit kronis memiliki pendapatan dibawah UMR $(51,4 \%)$ lebih besar dibandingkan dengan responden dengan penghasilan lebih dari UMR (48,6\%). Rohman dan Suroso (2013) menjelaskan bahwa jumlah pendapatan keluarga mendukung keluarga untuk mempersiapkan item-item yang diperlukan untuk persiapan menghadapi bencana seperti cadangan makanan dan minuman, obat-obatan, asuransi, tabungan dan lainlain yang membuat keluarga lebih siap menghadapi dampak yang timbul dari bencana. semakin tinggi pendapatan keluarga akan mempengaruhi tingkat kesiapsiagaan keluarga.

Hasil penelitian menunjukan sebagian besar keluarga dengan penyakit kronis memiliki tingkat pendidikan dasar (60\%) lebih besar dibandingkan dengan keluarga dengan tingkat pendidikan menengah (40\%). Seseorang memperoleh pengetahuan semakin banyak dengan menempuh jenjang pendidikan yang lebih tinggi. Semakin banyak pengetahuan yang diperoleh khususnya pengetahuan tentang kebencanaan diharapkan dapat meningkatkan kesiapsiagaan seseorang (Rohman \& Suroso, 2013). Hasil penelitian Djafri (2013) menunjukan terdapat hubungan antara tingkat pendidikan dan kesiapsiagaan menghadapi bencana. hal tersebut tidak sejalan dengan penelitian Linuwih (2015) yang menunjukan tidak terdapat hubungan antara tingkat pendidikan dengan kesiapsiagaan menghadapi bencana. 
Tabel 2. Distribusi Frekuensi Parameter Kesiapsiagaan Keluarga dengan penyakit kronik di Desa Sidorejo Tahun $2016(n=35)$

\begin{tabular}{lcc}
\hline \multicolumn{1}{c}{ Variabel } & f & \% \\
\hline Pengetahuan dan Sikap & 17 & 48.6 \\
\hline Siap & 18 & 51.4 \\
Kurang Siap & & \\
\hline Kebijakan Keluarga & 16 & 45.7 \\
\hline Siap & 19 & 54.3 \\
Kurang Siap & & \\
\hline Rencana Tanggap Darurat & 17 & 48.6 \\
\hline Siap & 18 & 51.4 \\
Kurang Siap & & 8.6 \\
\hline Sistem Peringatan Bencana & 3 & 91.4 \\
\hline Siap & 32 & \\
Kurang Siap & & 31.4 \\
\hline Sumberdaya & 11 & 68.6 \\
\hline Siap & 24 & 100.0 \\
\hline Kurang Siap & 35 & \\
\hline Total & & \\
\hline
\end{tabular}

Hasil penelitian tabel 2 menunjukan prosentase keluarga dalam melaksanakan kesiapsiagaan di Desa Sidorejo tertinggi adalah keluarga yang tidak siap dalam mengenal sistem peringatan bencana $(91,4 \%)$. Hasil analisis peneliti keluarga tidak siap dalam mengenal sistem peringatan bencana disebabkan kurangnya frekuensi pelatihan manajemen bencana yang dilakukan oleh pihak pemerintahan setempat. Dari hasil wawancara dengan warga setempat, didapatkan data bahwa responden yang tinggal dekat dengan puncak merapi menyampaikan terdapat pihak relawan ataupun pemerintah yang memberikan peringatan melalui pengeras suara masjid jika bencana akan terjadi, sedangkan responden yang tinggal lebih jauh dari puncak merapi menyampaikan tidak ada pengumuman atau pemberitahuan bahwa bencana akan terjadi dan mereka baru menyelamatkan diri setelah mengetahui Gunung Merapi sudah meletus.

Hasil penelitian menunjukan prosentase keluarga dalam melaksanakan kesiapsiagaan di Desa Sidorejo terendah adalah keluarga yang siap dalam mengenal sistem peringatan bencana $(8,6 \%)$. Hasil analisis peneliti rendahnya keluarga dalam 
memahami sistem peringatan bencana disebabkan tidak menyeluruhnya pelatihan terkait kebencanaan yang diberikan kepada warga desa Sidorejo. Bersadarkan hasil wawancara didapatkan bahwa pelatihan kebencanaan tidak diberikan secara menyeluruh kepada setiap warga melainkan diberikan hanya kepada tim relawan desa dan warga yang tinggal di kawasan terdekat dengan puncak merapi. Hal tersebut mengakibatkan banyak keluarga yang tidak siap dalam memperkirakan atau membaca tanda awal terjadinya bencana sehingga terlambat untuk mempersiapakan diri ketika bencana terjadi.

Paramesti (2011) memaparkan masyarakat memerlukan pelatihan kebencanaan dan sumber informasi mengenai peringatan bencana baik sumber tradisional maupun tehnologi untuk dapat mengenali bahwa bencana akan terjadi. Warning System merupakan salah satu elemen utama mitigasi bencana, sehingga mitigasi bencana dapat menjadi salah satu sarana masyarakat di kawasan rawan bencana untuk dapat lebih menambah wawasan tentang sistem peringatan bencana (FEMA, 2000). Tanpa adanya kedua hal diatas penduduk di kawasan rawan bencana akan menghadapi resiko dan dampak akibat bencana yang lebih besar

Tabel 3. Distribusi Frekuensi Kesiapsiagaan Keluarga dengan penyakit kronik di Desa Sidorejo Tahun $2016(n=35)$

\begin{tabular}{llc}
\hline $\begin{array}{l}\text { Kesiap siagaan keluarga } \\
\text { dengan penyakit Kronik }\end{array}$ & f & \% \\
\hline Siap & 20 & 57.1 \\
Kurang siap & 15 & 42.9 \\
\hline Total & 35 & 100 \\
\hline
\end{tabular}

Tabel 3 menunjukkan sebagian besar responden memiliki kesiapsiagaan dalam kategori siap $(57,1 \%)$. Analisis peneliti, berdasarkan parameter kesiapsiagaan keluarga, parameter pengetahuan dan sikap serta rencana tanggap darurat merupakan pertanyaan dengan jawaban benar tertinggi. Pengetahuan dan rencana tanggap darurat yang baik berpengaruh terhadap koordinasi keluarga dalam hal mempersiapkan kebutuhan yang diperlukan serta pada saat upaya penyelamatan sehingga dapat mendukung keluarga untuk meningkatkan kesiapsiagaannya. 
Hasil penelitian ini sejalan dengan Djafri (2013) yang menyatakan kemampuan koordinasi dan perencanaan yang baik antar keluarga akan meningkatkan kesiapsiagaan keluarga dalam menghadapi bencana.

Tabel 4. Hubungan Tipe keluarga dengan Kesiapsiagaan Keluarga dengan penyakit kronik di Desa Sidorejo Tahun $2016(n=35)$

\begin{tabular}{|c|c|c|c|c|c|c|c|}
\hline \multirow{3}{*}{$\begin{array}{c}\text { Tipe } \\
\text { Keluarga }\end{array}$} & \multicolumn{4}{|c|}{ Kesiapsiagaan } & \multirow{2}{*}{\multicolumn{2}{|c|}{ Total }} & \multirow[b]{2}{*}{$p$} \\
\hline & \multicolumn{2}{|c|}{ Siap } & \multicolumn{2}{|c|}{ Kurang siap } & & & \\
\hline & $\mathrm{f}$ & $\%$ & $\mathrm{f}$ & $\%$ & $\mathrm{f}$ & $\%$ & \multirow{4}{*}{0.241} \\
\hline Extended & 8 & 47.1 & 9 & 52.9 & 17 & 100.0 & \\
\hline Nuclear & 12 & 66.7 & 6 & 33. & 18 & 100.0 & \\
\hline Jumlah & 20 & 57.1 & 15 & 42.9 & 35 & 100.0 & \\
\hline
\end{tabular}

Tabel 4 menunjukan proporsi tipe keluarga responden terbanyak adalah tipe keluarga inti (nuclear family) sebanyak (51,4\%) dan merupakan tipe keluarga yang memiliki tingkat kesiapsiagaan siap lebih banyak $(66,7 \%)$. Hasil uji statistik Chisquare menunjukkan tidak ada hubungan yang bermakna antara tipe keluarga dengan kesiapsiagaan keluarga dalam menghadapi bencana.

Analisi peneliti, dilihat dari jawaban responden, sebagian besar memiliki kesiapsiagaan yang tinggi pada parameter pengetahuan dan sikap serta rencana tanggap darurat, yang menunjukkan bahwa responden dan keluarga telah memahami kerentanan bencana yang dapat terjadi di lingkungan dan bagaimana harus bersikap/bertindak ketika bencana tiba-tiba terjadi. Pengetahuan kebencanaan yang baik akan mempengaruhi keluarga dalam hal pembagian tugas dan bagaimana keluarga berkoordinasi dengan baik sehingga keluarga yang tinggal di kawasan rawan bencana dapat lebih mempersiapkan diri untuk menghadapi rangkaian peristiwa yang akan timbul akibat bencana. Pendapat ini didukung oleh penelitian yang dilakukan oleh Djafri (2013) yang menyatakan bahwa kemampuan koordinasi dan perencanaan yang baik antar keluarga akan meningkatkan kesiapsiagaan keluarga dalam menghadapi bencana. 
Tabel 5. Hubungan Karakteristik Keluarga yang memiliki anggota penyakit kronik dengan kesiap siagaan menghadapi bencana Di Desa Sidorejo Tahun $2016(n=35)$

\begin{tabular}{|c|c|c|c|c|c|c|c|}
\hline \multirow{3}{*}{ Karakteristik Keluarga } & \multicolumn{4}{|c|}{ Kesiapsiagaan } & \multirow{2}{*}{\multicolumn{2}{|c|}{ Total }} & \multirow[b]{3}{*}{$p$} \\
\hline & \multicolumn{2}{|c|}{ Siap } & \multicolumn{2}{|c|}{ Kurang Siap } & & & \\
\hline & $\mathrm{f}$ & $\%$ & $\mathrm{f}$ & $\%$ & \multirow[t]{2}{*}{$f$} & \multirow[t]{2}{*}{$\%$} & \\
\hline APGAR & & & & & & & \\
\hline Tidak ada disfungsi & 11 & 57.9 & 8 & 42.1 & 19 & 100.0 & \multirow{2}{*}{0.922} \\
\hline ada disfungi & 9 & 56.3 & 7 & 43.8 & 16 & 100.0 & \\
\hline \multicolumn{8}{|l|}{ Pendapatan } \\
\hline Diatas UMR & 11 & 91.7 & 1 & 8.3 & 22 & 100.0 & \multirow{2}{*}{0.000} \\
\hline Dibawah UMR & 9 & 39.1 & 14 & 60.9 & 13 & 100.0 & \\
\hline
\end{tabular}

\section{Tingkat Pendidikan}

\begin{tabular}{llllllll}
\hline Menengah & 7 & 50 & 7 & 50 & 14 & 100.0 & \multirow{2}{*}{0.486} \\
\cline { 1 - 6 } Dasar & 13 & 61.9 & 8 & 38.1 & 21 & 100.0 & \\
\hline Total & 20 & 57.1 & 15 & 42.9 & 35 & 100.0 &
\end{tabular}

Tabel 5 menunjukan bahwa proporsi keluarga dengan APGAR terbanyak adalah keluarga yang tidak terdapat adanya disfungsi keluarga (54,3\%). Keluarga yang tidak memiliki disfungsi merupakan keluarga dengan kesiapsiagaan kategori siap yang terbanyak (57,9\%). Hasil uji statistik Kendall-Tau menunjukan tidak ada hubungan antara APGAR keluarga dengan kesiapsiagaan keluarga dengan penyakit kronis dalam menghadapi bencana.

Hasil penelitian ini tidak sejalan dengan penelitian Susilawati (2013) yang menyatakan kepedulian dan dukungan anggota keluarga akan mempengaruhi keluarga saat melakukan persiapan dan peralatan yang diperlukan sebelum, saat dan setelah bencana terjadi. Hasil analisis peneliti, responden telah memiliki pengetahuan dan rencana tanggap darurat yang baik dilihat dari prosentase kesiapsiagaan kategori siap pada kedua parameter tersebut. Responden memahami tentang resiko bencana yang mereka hadapi di daerahnya dan tindakan yang harus dilakukan ketika bencana terjadi, seperti lokasi titik kumpul yang aman, alat komunikasi dan kontak yang dapat dihubungi untuk meminta pertolongan saat bencana terjadi, anggota keluarga yang menjadi prioritas untuk diselamatkan dan lain-lain. Sehingga anggota keluarga dapat segera melakukan upaya penyelamatan diri baik untuk dirinya sendiri ataupun anggota keluarganya yang lain. Sehingga dengan pengetahuan dan rencana tanggap darurat yang siap, kedekatan/skor 
APGAR tidak memberikan pengaruh yang signifikan terhadap kesiapsiagaan keluarga dengan penyakit kronis dalam menghadapi bencana.

Tabel 5 menunjukkan proporsi pendapatan keluarga hubungannya dengan kesiapsiagaan keluarga dengan penyakit kronis terbanyak adalah keluarga dengan pendapatan dibawah UMR $(51,4 \%)$ lebih besar dibandingkan dengan keluarga dengan pendapatan di atas UMR (48,6\%). Keluarga yang memiliki kesiapsiagaan dalam kategori siap terbanyak yaitu pada keluarga dengan pendapatan diatas UMR (91,7\%). Hasil uji statistik Kendall-Tau menunjukan adanya hubungan antara pendapatan keluarga dengan kesiapsiagan keluarga dalam menghadapi bencana. Hasil tersebut sejalan dengan hasil penelitian Rohman dan Suroso (2013) yang menyatakan terdapat hubungan antara pendapatan dengan kesiapsiagaan. Jumlah pendapatan keluarga mendukung keluarga untuk mempersiapkan item-item yang diperlukan untuk persiapan menghadapi bencana seperti cadangan makanan dan minuman, obat-obatan, asuransi, tabungan dan lain-lain yang membuat keluarga lebih siap menghadapi dampak yang timbul dari bencana.

Hasil analisis peneliti, keluarga dengan penyakit kronis yang berpendapatan diatas UMR memiliki kesiapsiagaan siap lebih tinggi karena dengan pendapatan yang dimiliki keluarga dapat melengkapi keperluan yang dibutuhkan oleh anggota keluarga selama berada di pengungian. Kemudian sebagian besar responden telah mengikuti program tabungan siaga bencana yang diselenggarakan oleh kerjasama ibu-ibu PKK dan pemerintah desa yang pada waktu yang telah ditertentukan setiap keluarga yang mengikuti program tersebut menabung sesuai dengan kemampuan masing-masing untuk dimasukan ke dalam tabungan. Kemudian tabungan dapat diambil pada saat terjadi bencana ataupun keadaan darurat lain. Selain itu setiap responden mengatakan telah mengikutsertakan anggota keluarganya terutama yang memiliki penyakit kronis dalam asuransi kesehatan yang diselenggarakan oleh pemerintah sehingga jika suatu waktu keluarga sakit atau pada keadaan darurat medis, keluarga dapat menggunakan fasilitas asuransi tersebut.

Tabel 5 menunjukan proporsi tingkat pendidikan terkait kesiapsiagaan terbanyak adalah keluarga dengan tingkat pendidikan dasar (60\%) dan proporsi 
keluarga dengan kategori siap terbanyak adalah keluarga dengan tingkat pendidikan dasar $(61,9 \%)$. Hasil uji statistik Kendall-Tau menunjukan tidak ada hubungan antara tingkat pendidikan dengan kesiapsiagaan keluarga dengan penyakit kronis.

Penelitian ini didukung dengan hasil penelitian dari Linuwih (2015) dan Sagala dkk (2014) yang menyatakan bahwa tidak terdapat hubungan antara tingkat pendidikan dan kesiapsiagaan bencana. Hasil analisi peneliti untuk memiliki pengetahuan yang baik tentang kesiapsigaan bencana, responden tidak harus selalu didapatkan dengan menempuh jalur pendidikan formal melainkan dari pembelajaran informal seperti mengikuti seminar/pelatihan terkait kebencanaan. Selain itu bertempat tinggal dalam waktu yang cukup lama di kawasan rawan bencana dan intensitas terjadinya bencana yang sering dihadapi membuat warga sekitar memahami kondisi kerentanan yang mereka hadapi. Pendapat diatas didukung oleh pendapat dari Haryanto (2012) yang disitasi oleh Novita (2015) memaparkan bahwa dengan dasar pengamatan sehari-hari dan pengalaman mengalami bencana itu sendiri membuat masyarakat di kawasan rawan bencana belajar tentang sifat/karakteristik kerentanan bencana yang ada di lingkungan mereka akan membuat kesiapsiagaan warga daam menghadapi bencana meningkatkan.

\section{SIMPULAN DAN SARAN}

Tipe keluarga, APGAR keluarga dan tingkat pendidikan tidak berhubungan dengan kesiapsiagaan keluarga dengan penyakit kronis. Terdapat hubungan antara pendapatan dengan kesiapsiagaan keluarga dengan penyakit kronis. Keluarga dengan penyakit kronis memiliki kesiapsiagaan dalam kategori siap. 


\section{RUJUKAN}

Aldrich dan Benson. 2008. Disaster Preparedness and the Chronic Disease Needs of Vulnerable Older Adults (jurnal). Centers for Disease Control and Prevention (CDC). Tersedia dalam: http://198.246.124.22/pcd/issues/2008/jan/pdf/07_0135.pdf [Diakses pada 11 Maret 2016 pukul 10:41]

Alia. 2014. BNPB: 1.525 Bencana Terjadi di Indonesia Selama 2014. Jakarta. Viva Media Baru. Tersedia dalam: http://nasional.news.viva.co.id/news/read/573877-bnpb--1-525-bencanaterjadi-di-indonesia-selama-2014 [Diakses pada 18 Februari 2016 pukul 10:50]

Anonim. 2013. The Devastating Impact of Natural Disasters. Child Fund International 2013. Tersedia dalam: https://www.childfund.org/Content/NewsDetail/2147489272/ [diakses pada 11 Mei 2016 jam 06.20]

Anonim. 2015. Kecamatan Kemalang dalam Angka Tahun 2014. Klaten. Badan Pusat Statistik Kabupaten Klaten. Tersedia dalam: http://klatenkab.bps.go.id/index.php/publikasi/112 [Diakses pada 16 Februari 2016 pukul 10:53]

Anonim. 2010. Dampak Kesehatan Akibat Letusan Gunung Merapi. Jakarta. Kementrian Luar Negeri Republik Indonesia. Tersedia dalam: http://www.kemlu.go.id/id/berita/informasi-penting/Pages/Dampak-KesehatanAkibat-Letusan-Gunung-Merapi.aspx [Diakses pada 18 Februari 2016 pukul 13:10]

Anonim. 2014. Dampak Letusan Gunung Berapi terhadap Kesehatan. Jakarta. Tempo.co. tersedia dalam https://www.tempo.co/read/news/2014/02/19/140555511/dampak-letusangunung-berapi-terhadap-kesehatan [Diakses pada 23 Februari 2016 pukul $13: 25]$

Anonim. 2015. Perkembangan Krisis Kesehatan Akibat Erupsi Gunung Sinabung. Jakarta. Kementrian Kesehatan Republik Indonesia. Tersedia dalam: http://www.penanggulangankrisis.depkes.go.id/perkembangan-krisiskesehatan-akibat-erupsi-gunung-sinabung [Diakses pada 18 Februari 2016 pukul 13:18]

Badan Nasional Penanggulangan Bencana Republik Indonesia.2010. Definisi dan Jenis Bencana.Tersedia dalam : http://www.bnpb.go.id/pengetahuanbencana/definisi-dan-jenis-bencana [diakses pada 11 Mei 2016 jam 06.09]

Badan Nasional Penanggulangan Bencana Republik Indonesia. 2015. Kerangka Kerja Sendai Untuk Pengurangan Risiko Bencana 2015-2030. Republik Indonesia [diakses pada 11 Mei 2016 jam 07.10] 
Badan Perencanaan Pembangunan Nasional.2006. Rencana Aksi Nasional Pengurangan Resiko Bencana 2006-2009.Tersedia dalam : http://www.bappenas.go.id/files/5113/5022/6066/versi-bahasaindonesia_20081122175120_826_0.pdf .[Diakses pada 19 Februari 2016 jam 10.11]

Badan pusat Statistik Klaten.2016. Kecamatan Kemalang dalam angka Kemalang in Figure. BPS Kabupaten Klaten.

Centre for Research on the Epidemiology of Disaster. 2014. World Disaster Report 2014. Amerika Serikat. International Federation of Red Cross. Tersedia dalam: http://www.ifrc.org/world-disasters-report-2014/data .[Diakses pada 25 Februari 2016 jam 10.30]

Djafri dan Nofrianti. 2013. Hubungan Tingkat Kesadaran dan Karakteristik Keluarga dengan Kesiapsiagaan dalam Menghadapi Gempa dan Tsunami di Kota Padang di Tahun 2013. Padang. FKM Universitas Andalas. Tersedia dalam: http://repo.unand.ac.id/327/ [diakses pada 4 Juni 2016 pukul 14:53].

International Frederation of Red Cross and Red Crescent Societies. What is a Disaster ? .Tersedia dalam: http://www.ifrc.org/en/what-we-do/disastermanagement/about-disasters/what-is-a-disaster/ [ diakses pada 16 April 2016 jam 15.20]

Irwan dan Nurul. 2010. Waspadai Lima Dampak Kesehatan Akibat Letusan Gunung Merapi. Jakarta. Detikcom. Tersedia dalam: http://news.detik.com/berita/1486531/waspadai-5-dampak-kesehatan-akibatletusan-gunung-merapi .[Diakses pada 25 Februari 2016 jam 10.20]

LIPI - UNESCO/ISDR.2006. Kajian Kesiapsiagaan Masyarakat dalam Mengantisipasi Bencana Gempa Bumi dan Tsunami.

Maplecroft. 2010. Natural Disaster Risk Index. Tersedia dalam: http://www.preventionweb.net/files/14169_NaturalDisasters2010.pdf [Diakses pada 19 Februari 2016 jam 10.11 ]

Mediastianto. 2015. Statistik Kejadian Bencana Tahun 2014. Jakarta. Kementrian Kesehatan Republik Indonesia. Tersedia dalam: http://www.penanggulangankrisis.depkes.go.id/statistik-kejadian-bencana-

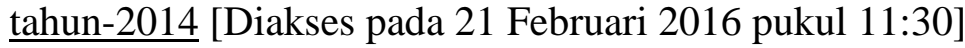

Miller dan Arquilla. 2008. Chronic Diseases and Natural Hazards: Impact of Disasters on Diabetic, Renal, and Cardiac Patients (jurnal). New York. The State University of New York Downstate Medical Center, Brooklyn, New York USA. Tersedia dalam: http://journals.cambridge.org/abstract_S1049023X00005835 [Diakses pada 18 Februari 2016 pukul 10:53] 
Owens dan Martsolf. 2014. Chronic Illness and Disasters: Development of a Theoretical Framework (Jurnal). Ohio. Ashland University, Ashland Ohio, USA. Tersedia dalam: https://www.dovepress.com/emergency-and-disasterpreparedness-for-chronically-ill-patients-a-rev-peer-reviewed-article-OAEM [Diakses pada 11 Maret 2016 pukul 11:19]

Rohman dan Suroso. 2013. Hubungan Antara Umur, Pendidikan, Pendapatan, dan Pengalaman Bencana dengan Kesiapsiagaan Tingkat Rumah Tangga (Studi Kasus: Banjir Kali Lamong Kabupaten Gresik). Bandung. Intitut Teknologi Bandung. Tersedia dalam: http://sappk.itb.ac.id/jpwk2/wpcontent/uploads/2013/11/V1N1-Hubungan-Antara-Umur-PendidikanPendapatan-dan-Pengalaman-Bencana-dengan-Kesiapsiagaan-Tingkat-RumahTangga1.pdf [diakses pada 13 April 2016 pukul 11:30]

Rohman M. 2013. Evaluasi Kesiapsiagaan Masyarakat Terhadap Bencana Gunung Merapi Di Desa Sidorejo, Kecamatan Kemalang, Kabupaten Klaten, Jawa Tengah. Surakarta. Fakultas Keguruan dan Ilmu Pendidikan Universitas Muhammadiyah Surakarta. Tersedia dalam: http://eprints.ums.ac.id/26535/19/NASKAH_PUBLIKASI.pdf [Diakses pada 26 Februari 2016 pukul 17:58].

Susilo. 2013. Analis Kesiapsiagaan Masyarakat terhadap Bencana Gunung Merapi di Desa Dompol, Kecamatan Kemalang, Kabupaten Klaten (Skripsi). Surakarta. Fakultas Keguruan dan Ilmu Pendidikan Universitas Muhammadiyah Surakarta. Tersedia dalam: http://eprints.ums.ac.id/27996/ [Diakses pada 26 Februari 2016 pukul 17:30].

Tomio dan Sato. 2014. Emergency and disaster preparedness for chronically ill patients: a review of recommendations. Tokyo. The University of Tokyo, Tokyo, Japan. Tersedia dalam: [diakses pada 19 februari 2016 pukul 10:54].

Wahyu. 2011. Perubahan Interaksi Sosial Pada Lansia Dengan Penyakit Kronis Di Panti Werdha Abadi/Dharma Asih Binja. Medan. Universitas Sumatra Utara. Tersedia dalam: http://repository.usu.ac.id/handle/123456789/24196 [diakses pada 13 April 2016 pukul 12:20].

World Health Organiation (WHO). 2016. Noncommunicable Disease. WHO International. Tersedia dalam: www.who.int/topics/noncommunicable_diseases/en/ [Diakses pada 11 Maret 2016 pukul 10:35].

Yusuf. 2015. Gambaran Kualitas Hidup Lansia Yang Mengalami Penyakit Kronis Di Puskesmas Dulalowo Kecamatan Kota Tengah Kota Gorontalo. Gorontalo. Universitas Negeri Gorontalo. Tersedia dalam: http://kim.ung.ac.id/index.php/KIMFIKK/article/download/11293/11166 [diakses pada 11 Mei 2016 jam 07.18] 